\title{
A Lipid Gate for the Peripheral Control of Pain
}

\author{
Daniele Piomelli, ${ }^{1,2}$ @Andrea G. Hohmann, ${ }^{3}$ Virginia Seybold, ${ }^{4}$ and Bruce D. Hammock ${ }^{5}$ \\ ${ }^{1}$ Departments of Anatomy and Neurobiology, Pharmacology and Biological Chemistry, University of California, Irvine, California 92697-1275, ${ }^{2}$ Department \\ of Drug Discovery and Development, Istituto Italiano di Tecnologia, Genova, Italy 16163, ${ }^{3}$ Department of Psychological and Brain Sciences and Program in \\ Neuroscience, and Gill Center for Biomolecular Science, Indiana University, Bloomington, Indiana 47405, ${ }^{4}$ Department of Neuroscience, University of \\ Minnesota, Minneapolis, Minnesota 55455, and ${ }^{5}$ Department of Entomology, University of California, Davies, California 95616-8584
}

Cells in injured and inflamed tissues produce a number of proalgesic lipid-derived mediators, which excite nociceptive neurons by activating selective G-protein-coupled receptors or ligand-gated ion channels. Recent work has shown that these proalgesic factors are counteracted by a distinct group of lipid molecules that lower nociceptor excitability and attenuate nociception in peripheral tissues. Analgesic lipid mediators include endogenous agonists of cannabinoid receptors (endocannabinoids), lipid-amide agonists of peroxisome proliferator-activated receptor- $\alpha$, and products of oxidative metabolism of polyunsaturated fatty acids via cytochrome $\mathrm{P}_{450}$ and other enzyme pathways. Evidence indicates that these lipid messengers are produced and act at different stages of inflammation and the response to tissue injury, and may be part of a peripheral gating mechanism that regulates the access of nociceptive information to the spinal cord and the brain. Growing knowledge about this peripheral control system may be used to discover safer medicines for pain.

\section{Introduction}

Harmful stimuli are detected by a class of specialized sensory neurons, called nociceptors, which are housed in the trigeminal and DRG and project their axons to the periphery of the body. These neurons are divided into two subclasses that are both structurally and functionally distinct. Medium-sized " $\mathrm{A} \delta$ " nociceptors convey the localized sharp pain sensation that acts as a warning sign of injury, whereas small-sized " $C$ " nociceptors mediate the more diffused and delayed pain that promotes defensive behaviors and supports tissue repair. In addition to mechanical and thermal insults (two common causes of body damage), nociceptors also respond to a variety of chemical irritants (e.g., defensive compounds produced by plants and insects) as well as to endogenous chemicals, such as protons, nucleotides, peptides, and lipid-derived mediators (for review, see Piomelli and Sasso, 2014).

Cells in injured and inflamed tissues generate a variety of proalgesic (pain-inducing or pain-enhancing) lipid mediators, which include membrane-derived phospholipids (e.g., lysophosphatidic acid and lysophosphatidylinositol), and oxidative

Received Aug. 19, 2014; revised Sept. 15, 2014; accepted Sept. 21, 2014.

This work was supported primarily by the National Institute on Drug Abuse, National Cancer Institute, National Institute of Environmental Health Sciences, National Institute of Arthritis and Musculoskeletal and Skin Diseases, and National Institute of Neurological Disorders and Stroke. D.P. holds the Louise Turner Arnold Chair in the Neurosciences. A.G.H. holds a Linda and Jack Gill Chair of Neuroscience and a Lilly Presidential Life Science Professorship.

Conflicts of interest:D.P. and B.D.H. are inventors in issued patents and patent applications filed by the University of California and the Fondazione Istituto Italiano di Tecnologia, which disclose pharmaceutical agents targeting molecular pathways described in the present article. B.D.H. is a cofounder of Eicosis LLC, which develops soluble epoxide hydrolase inhibitors. D.P. is a cofounder of Anteana Therapeutics Inc, which develops endocannabinoidbased medications, and Thesan Pharmaceuticals Inc, which develops dermatological therapies unrelated to the topic of the present article. The remaining authors declare no competing financial interests.

Correspondence should be addressed to Dr. Daniele Piomelli, University of California, Irvine, Department of Anatomy and Neurobiology, 3101 Gillespie Neuroscience Research Facility, Irvine, CA 92697-4625. E-mail: piomelli@uci.edu.

DOI:10.1523/JNEUROSCI.3475-14.2014

Copyright $\odot 2014$ the authors $\quad 0270-6474 / 14 / 3415184-08 \$ 15.00 / 0$ metabolites of polyunsaturated fatty acids (PUFAs) (e.g., prostaglandin $\mathrm{E}_{2}$, hydroxylated derivatives of linoleic acid) (Piomelli and Sasso, 2014) (Fig. 1). These molecules increase the excitability of nociceptive neurons by engaging selective G-proteincoupled receptors or ligand-gated ion channels. The specific roles played by each of these substances, if any, are often unknown, but their importance in inducing and maintaining pain has been recognized since the 1970s (Ferreira, 1972). Only recently has it become clear, however, that the proalgesic influence of these mediators is countered by the actions of a distinct set of bioactive lipids that modulate nociception by lowering sensory neuron excitability. These analgesic lipids include endocannabinoids, such as anandamide and 2-arachidonoyl-sn-glycerol (2-AG), lipidamide agonists of peroxisome proliferator-activated receptor- $\alpha$ (PPAR- $\alpha$ ), such as palmitoylethanolamide (PEA) and oleoylethanolamide (OEA), and various products of oxidative PUFA metabolism (Fig. 1). Here we review evidence indicating that these lipid-derived mediators modulate pain initiation by regulating the transmission of nociceptive signals from injury sites in peripheral tissues to the CNS.

\section{Endogenous cannabinoid agonists}

Anandamide and 2-AG are part of a signaling complex that also comprises G-protein-coupled cannabinoid receptors that mediate their effects $\left(\mathrm{CB}_{1}\right.$ and $\left.\mathrm{CB}_{2}\right)$ as well as proteins responsible for their production, transmembrane transport, and breakdown. These agents are produced and degraded through distinct enzymemediated routes (for review, see Guindon and Hohmann, 2009). Anandamide is formed by cleavage of a membrane phospholipid in which the amine group of phosphatidylethanolamine is covalently linked to arachidonic acid. Newly released anandamide acts near its sites of production, as an autocrine or paracrine messenger, and is rapidly eliminated through a process consisting of carrier-mediated transport into cells (the molecular mechanism of which remains unclear) followed by hydrolysis catalyzed 


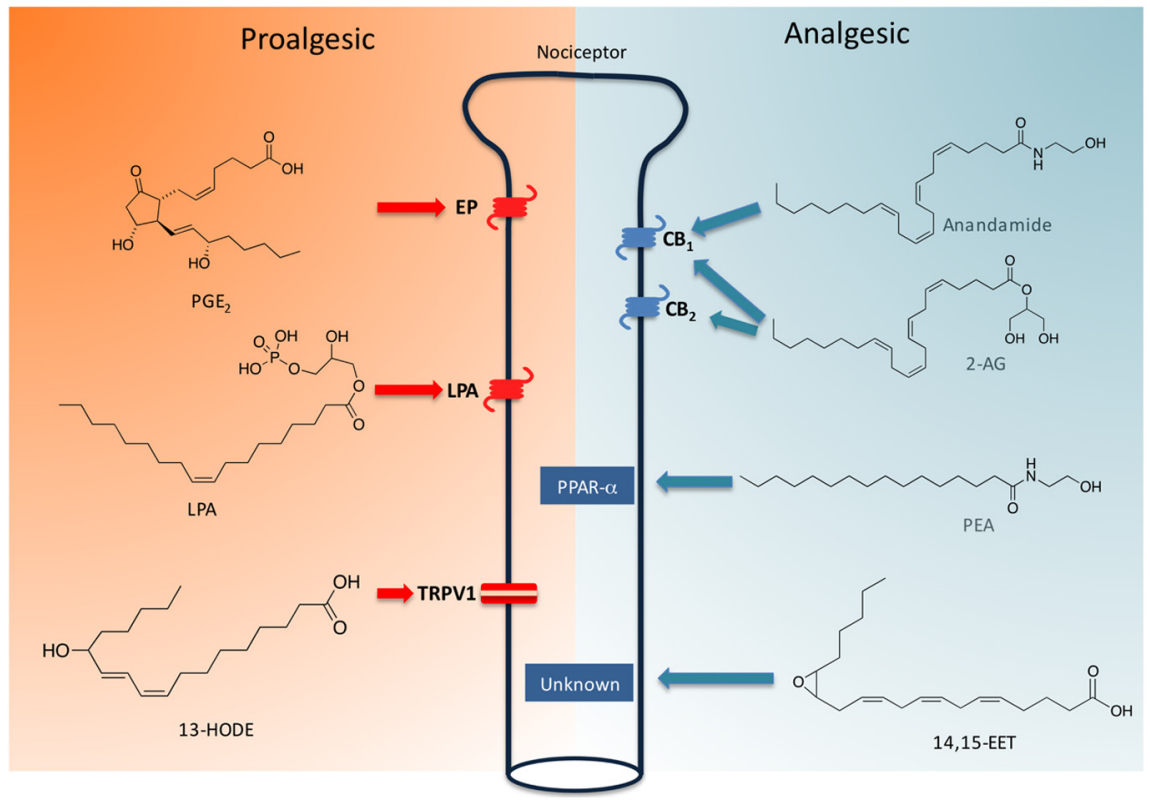

Figure 1. Peripheral gating of nociception by lipid-derived mediators. Lipid messengers generated by neural and non-neural cells during injury or inflammation regulate the excitability of peripheral nociceptors. Proalgesic lipids, which heighten nociceptor excitability, include prostanoids, such as prostaglandin $E_{2}$ (which binds to G-protein-coupled EP-type receptors), phospholipids, such as lysophosphatidic acid (LPA) (which binds to LPA receptors), and oxidized PUFA derivatives, such as 13-hydroxyoctadecenoic acid (13-HODE), which activates TRPV-1. Persistent TRPV-1 activation can lead to desensitization and consequent reduction in nociceptive signaling. Analgesic lipids, which dampen nociceptor excitability, include endocannabinoids, such as anandamide and 2-AG (which bind to $\mathrm{CB}_{1}$ and $\mathrm{CB}_{2}$ cannabinoid receptors), endogenous ligands for PPAR- $\alpha$, such as PEA, and oxidized PUFA derivatives, such as 14,15-EET. Anandamide can also activate TRPV-1, but at concentrations that are unlikely to be reached under most physiological conditions.

by the intracellular serine amidase, fatty acid amide hydrolase (FAAH) (Ueda et al., 2013). Anandamide can be also transformed by cyclooxygenase-2 into proalgesic metabolites called prostamides (Gatta et al., 2012). There are no known inhibitors of anandamide formation. By contrast, anandamide deactivation can be interrupted using agents that block membrane transport (e.g., AM404 or ARN272) (Fu et al., 2012), FAAH-mediated degradation (e.g., URB597) (Kathuria et al., 2003) (Fig. 2), or substrateselective cyclooxygenase metabolism (e.g., LM-4131) (Hermanson et al., 2013).

2-AG is produced in a series of reactions that starts with the conversion of phosphatidylinositol-4,5-bisphosphate into 1,2diacylglycerol (1,2-DAG), which is catalyzed by phospholipase C- $\beta$. 1,2-DAG is then cleaved by diacylglycerol lipase- $\alpha$ (DGL- $\alpha$ ) to form 2-AG and free fatty acid (Stella et al., 1997). Monoacylglycerol lipase (MGL) is the main serine esterase involved in 2-AG deactivation (Dinh et al., 2002; Hohmann et al., 2005), with $\alpha-\beta$ hydrolase domain 6 (ABHD-6) participating in some cases (Marrs et al., 2010). Like anandamide, 2-AG may be also metabolized by cyclooxygenase- 2 to produce oxidized proalgesic derivatives (for review, see Guindon and Hohmann, 2008). 2-AG formation can be inhibited using relatively nonselective probes that block either PLC (e.g., U73122) or DGL (e.g., tetrahydrolipstatin) (Gregg et al., 2012). DGL- $\alpha$-preferring inhibitors have been recently disclosed but remain to be fully characterized (Appiah et al., 2014). Agents interfering with 2-AG deactivation include compounds that target MGL (e.g., URB602 and JZL-184) (Hohmann et al., 2005; Long et al., 2009) and ABHD-6 (e.g., WWL-70) (Marrs et al., 2010) (Fig. 2).

\section{Endocannabinoid control of peripheral pain}

Although highly expressed in neurons of the brain and spinal cord (Herkenham, 1991), $\mathrm{CB}_{1}$ cannabinoid receptors are also present in neural and non-neural cells throughout the body (for review, see Guindon and Hohmann, 2009). They are synthesized in cell bodies of DRG neurons and are transported to peripheral nerve terminals, where they are localized appropriately to control pain initiation in response to agonist stimulation (Hohmann and Herkenham, 1999). Indeed, cellspecific deletion of $\mathrm{CB}_{1}$ in mouse nociceptive neurons impairs the antinociceptive effects of local or systemic (but not intrathecal) administration of cannabinoid agents (Agarwal et al., 2007). $\mathrm{CB}_{2}$ receptors, on the other hand, are primarily found in immune cells, such as Blymphocytes and macrophages, but are also present in skin keratinocytes and other cell types (Dhopeshwarkar and Mackie, 2014). Their expression in nociceptors is very low under baseline conditions but can be enhanced by injury or inflammation (Wotherspoon et al., 2005; Svízenská et al., 2013). Antihypersensitivity mechanisms mediated by peripheral $\mathrm{CB}_{1}$ receptors were first documented using local injections of anandamide (Calignano et al., 1998; Richardson et al., 1998). In subsequent studies, the antinociceptive actions of this compound were confirmed to be $\mathrm{CB}_{1}$-dependent, whereas the antinociceptive effects of 2-AG were shown to require activation of both $\mathrm{CB}_{1}$ and $\mathrm{CB}_{2}$ receptors (Guindon and Hohmann, 2009). When administered at the site of injury, cannabinoid agonists suppress the activity of nociceptive neurons in the spinal cord, suggesting that cannabinoid receptor occupancy outside the CNS is sufficient to control nociception (Nackley et al., 2003a, b, 2004; Sagar et al., 2005). In addition to cannabinoid receptors, anandamide can activate various ligand-gated ion channels, including transient receptor potential vanilloid-1 (TRPV-1) (Akopian et al., 2009). This activation requires, however, relatively high concentrations of anandamide, which are unlikely to occur in vivo, and its physiological significance remains unclear. For example, submicromolar concentrations of anandamide suppress the activity of somatosensory neurons (Khasabova et al., 2008), whereas the same neurons are excited by anandamide at concentrations $\geq 10 \mu \mathrm{M}$ through a TRPV-1-dependent mechanism (Price et al., 2004). Notably, a variety of lipid mediators have been shown to engage TRPV-1 more potently than does anandamide, including the nonendocannabinoid FAAH substrate OEA (LoVerme et al., 2006).

Several laboratories have attempted to harness the therapeutic potential of peripheral endocannabinoid signaling using inhibitors of anandamide and 2-AG deactivation, with a goal of alleviating pain states without causing unwanted CNS-based side effects. Pharmacological blockade of either MGL or FAAH at injury sites produces marked antinociception: FAAH and MGL inhibitors, administered locally into the paw, reduce behavioral hypersensitivity provoked by intraplantar injections of capsaicin 
in a modality-specific fashion and with nonoverlapping patterns of pharmacological selectivity (Spradley et al., 2010). Local MGL inhibition with the compound JZL-184 suppresses capsaicinevoked nocifensive behavior and heat hypersensitivity through both $\mathrm{CB}_{1}$ - and $\mathrm{CB}_{2}$-selective mechanisms, without altering capsaicin-evoked mechanical allodynia. By contrast, local injection of the FAAH inhibitor URB597 selectively blocks capsaicin-evoked mechanical allodynia, through $\mathrm{CB}_{1}$ activation, without changing nocifensive behavior or heat hypersensitivity (Spradley et al., 2010). In a model of inflammatory nociception, MGL inhibitors act peripherally to heighten the effects of endogenously produced 2-AG via both $\mathrm{CB}_{1}$ and $\mathrm{CB}_{2}$ receptors (Guindon et al., 2011). By contrast, in the same model, the antinociceptive effects of FAAH inhibitors are exclusively mediated by $\mathrm{CB}_{1}$, whereas their anti-inflammatory actions require $\mathrm{CB}_{2}$ and PPAR- $\alpha$ (presumably via PEA/OEA augmentation, see Endogenous PPAR- $\alpha$ agonists) (Guindon and Hohmann, 2009; Clapper et al., 2010). The development of a brain-impermeant FAAH inhibitor, URB937, allowed researchers to demonstrate unambiguously that anandamide controls pain initiation through a peripheral $\mathrm{CB}_{1}$-dependent mechanism (Clapper et al., 2010). URB937, which is actively extruded from the CNS by the action of an ATP-binding cassette transporter (Moreno-Sanz et al., 2011), suppresses formalin-evoked pain behaviors and neuronal activation in the spinal cord and produces $\mathrm{CB}_{1}$-mediated antinociception in models of nerve injury and inflammation (Clapper et al., 2010; Sasso et al., 2012). Collectively, these observations indicate that anandamide and 2-AG play nonredundant roles in the control of peripheral nociception.

In a model of peripheral neuropathy caused by the chemotherapeutic agent, cisplatin, the globally active FAAH inhibitor, URB597, prevents the development of allodynia, normalizes cisplatin-induced decrease in conduction velocity of $\mathrm{A} \alpha / \mathrm{A} \beta$ fibers and reduces the increase in immunoreactivity for TRPV-1 and the injury marker ATF3 in DRG neurons (Khasabova et al., 2012). Its brain-impermeant counterpart, URB937, and the MGL inhibitor JZL-184 are also effective in suppressing mechanical and cold allodynia but act through distinct mechanisms: $\mathrm{CB}_{1}$, $\mathrm{CB}_{2}$, and TRPV-1 antagonists block the antiallodynic effects of URB937 (and URB597), whereas those of JZL-184 are prevented by $\mathrm{CB}_{1}$ and $\mathrm{CB}_{2}$ antagonists only (Guindon et al., 2013). The finding that TRPV-1 antagonists block the antinociceptive actions of URB937 underscores the complexity of the molecular response to FAAH inhibition, which cannot be simplistically equated to enhanced anandamide activity at cannabinoid receptors.

Cisplatin stimulates the mobilization of anandamide and 2-AG in lumbar spinal cord tissue but lowers 2-AG content in DRG (Guindon et al., 2013). In lumbar spinal cord, cisplatin heightens FAAH transcription, suggesting that compensatory
B<smiles>CCCCCCC/C=C\C/C=C\C/C=C\CCCC(=O)OC(CO)CO</smiles>
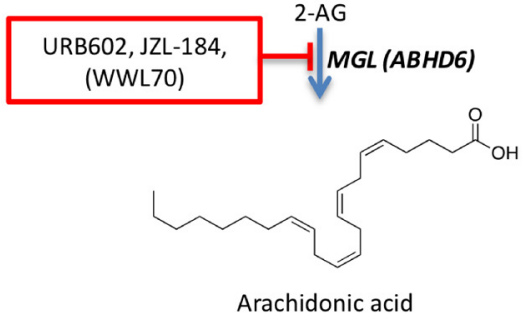

D
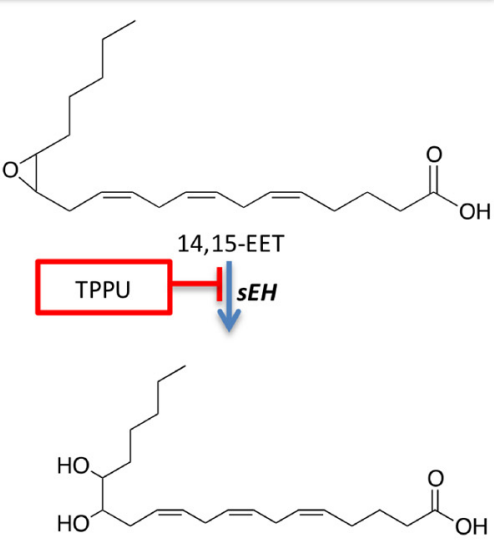

14,15-DHET

Figure 2. Targeting analgesic lipid-derived mediators for pain control. Protecting analgesic lipid messengers from enzymeABD-6 is inhibited by WWL-70. C, PEA and OEA are hydrolyzed by NAAA. ARN077 inhibits NAAA with high potency and selectivity but is metabolically unstable and cannot be used systemically. D. Epoxides of polyunsaturated fatty acids, such as 14,15-EET, are hydrolyzed by sEH, which is inhibited by compounds such as 1-trifluoromethoxyphenyl-3-(1-propionylpiperidin-4-yl) urea (TPPU).

changes in FAAH activity may result from the ability of this cytotoxic drug to elevate anandamide levels (Guindon et al., 2013). Moreover, traumatic nerve injury increases anandamide and 2-AG content, as well as $\mathrm{CB}_{1}$ expression, in DRG (Mitrirattanakul et al., 2006). It appears, therefore, that antinociceptive endocannabinoid signaling is upregulated in both CNS and peripheral nervous system during painful states.

The data summarized above suggest that activation of $\mathrm{CB}_{1}$, $\mathrm{CB}_{2}$, and possibly other receptors downstream of inhibition of endocannabinoid degradation alleviates pain via a peripheral mechanism. Are both $\mathrm{CB}_{1}$ and $\mathrm{CB}_{2}$ required for this response or is $\mathrm{CB}_{2}$ activation alone sufficient to control pain? To address this question, the antinociceptive efficacy of the $\mathrm{CB}_{2}$-preferring agonist AM1710 was evaluated in a model of chemotherapy-induced pain. Chronic dosing with AM1710 caused a marked suppression of pain responses (Deng et al., 2014). Importantly, these effects were absent in mutant mice lacking $\mathrm{CB}_{2}$ receptors and occurred in the absence of tolerance, $\mathrm{CB}_{1}$-dependent withdrawal or cardinal signs of $\mathrm{CB}_{1}$ activation (Deng et al., 2014). Additionally, treatment with AM1710 decreased transcription of mRNAs encoding for proinflammatory cytokines (e.g., tumor necrosis factor- $\alpha$ ) and chemokines (e.g., monocyte chemoattractant protein-1) in lumbar spinal cord (Deng et al., 2014). Thus, similarly to periph- 
eral blockade of endocannabinoid degradation, $\mathrm{CB}_{2}$ receptors activation exhibits a favorable therapeutic ratio marked by sustained efficacy in the absence of tolerance, physical withdrawal, $\mathrm{CB}_{1}$-mediated side effects, and drug abuse liability.

\section{Endogenous PPAR- $\alpha$ agonists}

PPAR- $\alpha$ is a lipid-activated nuclear receptor that serves key functions in the control of energy metabolism (Gervois and Mansouri, 2012). In addition to liver and muscle, where PPAR- $\alpha$ is highly expressed, the receptor is also found in other cell types, including DRG neurons (LoVerme et al., 2006) and macrophages (Gervois and Mansouri, 2012). Consistent with this localization, synthetic PPAR- $\alpha$ agonists (e.g., GW7647 and Wy-14643) suppress pain-related behaviors produced in rats and mice by injection of carrageenan, formalin, or magnesium sulfate (Taylor et al., 2002; LoVerme et al., 2006), prevent formalin-induced firing of rat spinal cord neurons (LoVerme et al., 2006), and show remarkable anti-inflammatory properties in animal models (Taylor et al., 2002; Kostadinova et al., 2005; LoVerme et al., 2005). Moreover, PPAR- $\alpha$ agonists reduce thermal and mechanical hyperalgesia evoked in mice by nerve injury or inflammation (LoVerme et al., 2006). PPAR- $\alpha$-null animals are insensitive to the antinociceptive effects of PPAR- $\alpha$ agonists but are hypersensitive to various proalgesic and proinflammatory stimuli (Devchand et al., 1996; Ruiz-Medina et al., 2012), which is suggestive of a role for PPAR- $\alpha$ in the tonic control of nociception and inflammation.

A variety of naturally occurring fatty-acid derivatives are agonists for PPAR- $\alpha$. These include low-potency ligands, such as free fatty acids, and high-potency ligands, such as OEA and PEA (Fig. 1). The median effective concentration $\left(\mathrm{EC}_{50}\right)$ values for PPAR- $\alpha$ activation are $0.12 \mu \mathrm{m}$ for OEA and $3 \mu \mathrm{M}$ for PEA (Fu et al., 2003; LoVerme et al., 2005). Evidence indicates that OEA and PEA exert a tonic inhibitory control over the induction of nociceptive responses. First, DRG neurons produce substantial amounts of these lipid amides, even in the absence of external stimuli. Because of this constitutive production, OEA and PEA reach singledigit micromolar concentrations in nonstimulated cells, which should be sufficient to engage a substantial fraction of local PPAR- $\alpha$ (Piomelli and Sasso, 2014). Second, proinflammatory stimuli suppress the formation of OEA and PEA. For example, macrophages exposed to bacterial endotoxin respond with a persistent decrease in OEA and PEA content (Solorzano et al., 2009), which results from a downregulation in the transcription of $\mathrm{N}$-acylphosphatidylethanolamine-selective phospholipase D (Zhu et al., 2011), the enzyme responsible for the biosynthesis of these lipid mediators (Rahman et al., 2014). Consistent with a role for OEA and PEA in inflammatory pathology, synovial fluid from subjects with rheumatoid arthritis and osteoarthritis contains lower concentrations of these lipid amides than does synovial fluid from healthy controls (Richardson et al., 2008).

The idea that lipid-amide agonists of PPAR- $\alpha$ are homeostatic regulators of nociception is supported by experiments using pharmacological agents that block $N$-acylethanolamine acid amidase (NAAA) (Solorzano et al., 2009; Khasabova et al., 2013; Sasso et al., 2013), a cysteine amidase that catalyzes the hydrolysis of PEA and OEA in macrophages and, possibly, other cells (Ueda et al., 2013) (Fig. 2). For example, topical applications of the potent and selective, but metabolically unstable, NAAA inhibitor ARN077 restore baseline OEA and PEA levels in inflamed skin tissue and attenuate nociceptive responses elicited in mice and rats by carrageenan injection, sciatic nerve ligation, or ultraviolet B-radiation (Sasso et al., 2013). These effects are absent in PPAR- $\alpha$-null mice and are prevented, in rats, by the PPAR- $\alpha$ antagonist GW6471 (Sasso et al., 2013). A possible interpretation of the findings outlined above, and those discussed in the next section, is that PEA and OEA contribute to the maintenance of hostdefense homeostasis by preventing the launch of inappropriate nociceptive and inflammatory responses. A full test of this hypothesis will require, however, the development of new experimental tools, including systemically active NAAA inhibitors.

\section{The role of lipid amides in tumor-evoked hyperalgesia}

The tumor microenvironment contains a variety of lipid substances (among other factors) that heighten the sensitivity of primary sensory neurons (Mantyh et al., 2002), thereby promoting hyperalgesia and spontaneous pain. Lipid mediators that activate PPAR- $\alpha$ (e.g., OEA and PEA) or $\mathrm{CB}_{1}$ receptors (e.g., anandamide) reduce the release of these substances by suppressing the immune system (O'Sullivan and Kendall, 2010) as well as the proliferation of tumor cells (Guindon and Hohmann, 2011; Pisanti et al., 2013). In addition to these indirect mechanisms, lipid amides also stimulate PPAR- $\alpha$ or $\mathrm{CB}_{1}$ in somatosensory neurons to reduce nociception directly. Estimates that $>75 \%$ of cancer patients experience moderate to severe pain that is poorly managed by opioid treatment (Mercadante, 1999) generates interest in the analgesic properties of these lipid mediators.

The roles of endogenous PPAR- $\alpha$ and cannabinoid ligands in tumor-evoked hyperalgesia have been studied both in vitro and in vivo. In an early animal model, osteolytic sarcoma cells were injected into the intramedullary space of the femur in a syngeneic mouse (Schwei et al., 1999). However, this protocol did not readily lend itself to electrophysiological recordings and was modified by injecting tumor cells into the calcaneous bone (Cain et al., 2001; Wacnik et al., 2001). In this latter model, osteolytic damage occurs within $6 \mathrm{~d}$ and is accompanied by mechanical hyperalgesia, spontaneous nocifensive behavior, and spontaneous C-fiber activity (Cain et al., 2001; Wacnik et al., 2001; Khasabova et al., 2013). An intimate relationship between sensory neurons and tumor cells develops: innervation of tumors with fibers immunoreactive for calcitonin gene-related peptide (a proalgesic and proinflammatory peptide) parallels the development of mechanical hyperalgesia (Wacnik et al., 2005).

An in vitro coculture model was developed to study the effects of chemical mediators released from cancer cells on DRG neurons: in this model, sarcoma cells plated on a cover glass condition the medium bathing a second cover glass on which mouse DRG neurons are plated (Khasabova et al., 2007). Parallel changes in lipid-amide signaling in small-diameter DRG neurons from tumor-bearing mice or naive mice maintained in medium conditioned by sarcoma cells (Khasabova et al., 2008, 2012, 2013) validate the reliability of this in vitro system to study tumor-evoked changes in neurons that are most likely to give rise to nociceptors (Hiura and Sakamoto, 1987; Pearce and Duchen, 1994). Moreover, the data generated in this model support the conclusion that factors released by cancer cells produce long-term alterations in sensory neurons, which contribute to tumor-evoked pain.

Reductions in the levels of PEA and anandamide in DRG that innervate the tumor as well as in DRG from naive mice cultured with sarcoma cells have been observed. One factor that contributes to lowering lipid amide levels is increased enzyme-mediated hydrolysis. The activities of both FAAH (Khasabova et al., 2008) and NAAA (Khasabova et al., 2012) are higher in DRG from tumor-bearing mice and DRG cocultured with sarcoma cells than in control DRG. The increase in enzyme activity is accompanied by accrued FAAH transcription (Khasabova et al., 2008). 
Diminished levels of bioactive lipid amides are also likely to contribute to tumor-related nociception because local injections of URB597 or ARN077, two selective inhibitors of FAAH and NAAA activities, respectively (Fig. 2) (Kathuria et al., 2003; Sasso et al., 2013), each reduce hyperalgesia in tumor-bearing paws (Khasabova et al., 2008, 2012). $\mathrm{A} \mathrm{CB}_{1}$ antagonist prevented the effects of URB597. In addition, local administration of PPAR- $\alpha$ or $\mathrm{CB}_{1}$ antagonists in naive mice evokes hyperalgesia (Khasabova et al., 2008, 2012), underscoring the importance of basal activation of these receptors by endogenous ligands in setting the threshold for nociception in naive subjects.

When DRG cells are cocultured with sarcoma cells, the physiological changes in small-diameter DRG neurons parallel those seen in vivo. Small DRG neurons from tumor-bearing or naive mice maintained in coculture with tumor cells exhibit larger $\mathrm{Ca}^{2+}$ transients following depolarization with potassium chloride, compared with control neurons (Khasabova et al., 2007, 2012). In the coculture condition, $\mathrm{CB}_{1}$ agonists reduce the amplitude of the depolarization-evoked $\mathrm{Ca}^{2+}$ transient, an effect mimicked by FAAH inhibition. $\mathrm{CB}_{1}$ blockade prevents the actions of both $\mathrm{CB}_{1}$ agonists and $\mathrm{FAAH}$ inhibitors.

The effects of the NAAA inhibitor ARN077 on DRG neurons parallel those of URB597 but are mechanistically different in that they require PPAR- $\alpha$ rather than $\mathrm{CB}_{1}$ receptors (Khasabova et al., 2012). This is confirmed by the ability of the endogenous PPAR- $\alpha$ agonist, PEA, to mimic the actions of ARN077 (Khasabova et al., 2012). Interestingly, PPAR- $\alpha$ activation has no effect on neurons maintained in vitro in the absence of sarcoma cells, but PPAR- $\alpha$ blockage increases the amplitude of depolarizationevoked $\mathrm{Ca}^{2+}$ transient (Khasabova et al., 2012). This result supports the possibility, mentioned above, that PPAR- $\alpha$ may be saturated by endogenous ligands under basal conditions (Piomelli and Sasso, 2014).

\section{Epoxy fatty acids in inflammatory and neuropathic pain}

Epoxides of arachidonic acid and other PUFAs (collectively called epoxy fatty acids [EpFAs]) (Fig. 1) are powerful modulators of nociception (Wagner et al., 2011; Inceoglu et al., 2012). They are generated by the cytochrome $\mathrm{P}_{450}$ pathway $(\mathrm{A}-\mathrm{C}, \mathrm{E})$ (Morisseau and Hammock, 2013), which is divided into two branches: one leads to products of $\omega$ and $\omega$-1 hydroxylation, which are generally proalgesic and proinflammatory, and another generates the EpFAs. The latter class includes epoxyeicosatrienoic acids (EETs) produced from the $\omega-6$ PUFA, arachidonic acid, which are predominantly analgesic and anti-inflammatory and are rapidly converted to corresponding dihydroxyeicosatrienoic acids (Wagner et al., 2011). The EpFAs also include derivatives of $\omega$-3 PUFAs, such as eicosapentaenoic acid and docosahexaenoic acid (Morisseau et al., 2010). Evidence suggests that $\omega$-3 EpFAs are important contributors to the positive biological outcomes of diets high in fish-derived $\omega$-3 PUFAs (Wagner et al., 2011; Morisseau and Hammock, 2013; Zhang et al., 2014). Even though epoxides are strained and sometimes reactive, three-membered cyclic ethers, most EpFAs are quite stable chemically. They are rapidly degraded, however, by a $\alpha / \beta$-hydrolase fold enzyme termed soluble epoxide hydrolase (sEH or EH2) (Morisseau and Hammock, 2013) (Fig. 2). Because of the low $\mathrm{K}_{\mathrm{m}}$ and high $\mathrm{k}_{\mathrm{cat}}$ of sEH for most EpFAs (Morisseau et al., 2010), these mediators are controlled as much by their degradation as by their biosynthesis. The fact that EpFA activity is regulated by biochemical mechanisms similar to those discussed above for other analgesic lipid mediators emphasizes the general roles played by such mechanisms in the control of analgesic lipid signaling.
Research on the cytochrome $\mathrm{P}_{450}$ pathway of PUFA metabolism lagged behind other branches for multiple reasons. A major one is that it was difficult to show biological activities of EpFAs because of their rapid cleavage by $\mathrm{sEH}$. Once this problem was overcome by the invention of potent $\mathrm{sEH}$ inhibitors (Shen and Hammock, 2012), other factors, including low titers of bioactive metabolites, difficulties in analysis, and lack of high-quality standards, continued to slow down progress. Nevertheless, experiments using sEH inhibitors have clearly demonstrated that EpFAs are involved in a variety of biological processes (Panigrahy et al., 2013; Zhang et al., 2013; Ulu et al., 2014). Some of the most dramatic effects of these agents (and thus, by inference, the EpFAs they protect) have been observed in animal models of inflammation. Rodent sepsis models were used to show that $\mathrm{sEH}$ blockade increases EET levels and concomitantly attenuates the burst in proalgesic prostaglandins triggered by bacterial endotoxin (Schmelzer et al., 2005).

Based on observations made in the sepsis model, sEH inhibitors were used to modulate levels of EET and other EpFAs in a variety of experimental contexts. The compounds prevent and reverse cardiac and pulmonary dysfunction (i.e., atrial fibrillation, fibrosis and cardiac hypertrophy, reduced onset of atherosclerosis, pulmonary fibrosis, chronic obstructive pulmonary disease, pulmonary hypertension) as well as a variety of pathological inflammatory states (e.g., gastrointestinal inflammation, vascular inflammation, stroke, ischemia-reperfusion injury, renal inflammation, and fibrosis), mitochondrial dysfunction, and chemical-induced nephrotoxicity (Morisseau and Hammock, 2013). Probably related to reduced sensitivity to reactive oxygen species and endoplasmic stress responses, $\mathrm{sEH}$ inhibitors increase pancreatic islet size, improve glucose homeostasis, and lower insulin resistance (Xu et al., 2006; Shen and Hammock, 2012; Morisseau and Hammock, 2013).

Consistent with their anti-inflammatory effects, sEH inhibitors attenuate nociceptive responses produced by a variety of inflammatory agents in rodents (Schmelzer et al., 2006). Interestingly, the inhibitors reduce pain responses produced by administration of $\mathrm{PGE}_{2}$, suggesting that they may work downstream of cyclooxygenase and its proalgesic metabolites (Inceoglu et al., 2011). Equally intriguing is the ability of sEH blockage to reduce pain behaviors in models of diabetes and nerve damage (Inceoglu et al., 2012). Whether monitoring mechanical allodynia or using a conditioned placement preference test, $\mathrm{sEH}$ inhibitors outperform gabapentin yet are devoid of the cognitive and motoric side effects commonly associated with use of this centrally active analgesic (Inceoglu et al., 2012). Interestingly, cyclooxygenase inhibitors, which have no effect on neuropathic pain responses when administered alone, synergistically reduce such responses when they are combined with sEH blockers (Guedes et al., 2013). The mechanism of action of sEH inhibitors in analgesia is still unknown, although neurosteroids appear to be involved (Inceoglu et al., 2013).

In conclusion, putting the available data together, we can conjecture that three distinct classes of bioactive lipid mediators (endocannabinoids, endogenous PPAR- $\alpha$ activators, and oxidative products of PUFA metabolism) regulate the transmission of nociceptive information from peripheral sites of injury and inflammation to the CNS. The data also raise several interesting questions. The first pertains to the existence of mechanisms, both local and systemic, which might regulate the correct deployment of analgesic lipid signals after tissue damage. Particularly important in this context may be the role of the autonomic nervous system, which is known to control endocannabinoid and OEA 
signaling in the gut (DiPatrizio et al., 2011) and the adipose organ (LoVerme et al., 2006). Another relevant question concerns the stages of injury or inflammation at which analgesic lipids might intervene. As mentioned above, there is evidence that the endogenous PPAR- $\alpha$ agonists, PEA and OEA, help set the threshold for nociception in intact tissues and that proinflammatory stimuli may act, at least in part, by disabling this homeostatic control system. By contrast, endocannabinoids, such as anandamide, may be released on demand during injury to offset the effects of local proalgesic signals, whereas products of oxidative PUFA metabolism, including the EpFAs and others, such as lipoxins and resolvins (Serhan et al., 2008), may help restore normal nociceptive responses during resolution and tissue healing (Piomelli and Sasso, 2014). Disruptions in the temporal unfolding of this program may contribute to the development of pathological pain conditions and might be targeted to discover better medicines for pain.

\section{References}

Agarwal N, Pacher P, Tegeder I, Amaya F, Constantin CE, Brenner GJ, Rubino T, Michalski CW, Marsicano G, Monory K, Mackie K, Marian C, Batkai S, Parolaro D, Fischer MJ, Reeh P, Kunos G, Kress M, Lutz B, Woolf CJ, et al. (2007) Cannabinoids mediate analgesia largely via peripheral type 1 cannabinoid receptors in nociceptors. Nat Neurosci 10: 870-879. CrossRef Medline

Akopian AN, Ruparel NB, Jeske NA, Patwardhan A, Hargreaves KM (2009) Role of ionotropic cannabinoid receptors in peripheral antinociception and antihyperalgesia. Trends Pharmacol Sci 30:79-84. CrossRef Medline

Appiah KK, Blat Y, Robertson BJ, Pearce BC, Pedicord DL, Gentles RG, Yu XC, Mseeh F, Nguyen N, Swaffield JC, Harden DG, Westphal RS, Banks MN, O'Connell JC (2014) Identification of small molecules that selectively inhibit diacylglycerol lipase-alpha activity. J Biomol Screen 19:595605. CrossRef Medline

Cain DM, Wacnik PW, Eikmeier L, Beitz A, Wilcox GL, Simone DA (2001) Functional interactions between tumor and peripheral nerve in a model of cancer pain in the mouse. Pain Med 2:15-23. CrossRef Medline

Calignano A, La Rana G, Giuffrida A, Piomelli D (1998) Control of pain initiation by endogenous cannabinoids. Nature 394:277-281. CrossRef Medline

Clapper JR, Moreno-Sanz G, Russo R, Guijarro A, Vacondio F, Duranti A, Tontini A, Sanchini S, Sciolino NR, Spradley JM, Hohmann AG, Calignano A, Mor M, Tarzia G, Piomelli D (2010) Anandamide suppresses pain initiation through a peripheral endocannabinoid mechanism. Nat Neurosci 13:1265-1270. CrossRef Medline

Deng L, Guindon J, Cornett BL, Makriyannis A, Mackie K, Hohmann AG (2014) Chronic cannabinoid receptor 2 activation reverses paclitaxel neuropathy without tolerance or cannabinoid receptor 1-dependent withdrawal. Biol Psychiatry. Advance online publication. Retrieved Apr 25, 2014. doi: 10.1016/j.biopsych.2014.04.009. CrossRef Medline

Devchand PR, Keller H, Peters JM, Vazquez M, Gonzalez FJ, Wahli W (1996) The PPARalpha-leukotriene B4 pathway to inflammation control. Nature 384:39-43. CrossRef Medline

Dhopeshwarkar A, Mackie K (2014) CB2 cannabinoid receptors as a therapeutic target: what does the future hold? Mol Pharmacol 86:430-437. CrossRef Medline

Dinh TP, Carpenter D, Leslie FM, Freund TF, Katona I, Sensi SL, Kathuria S, Piomelli D (2002) Brain monoglyceride lipase participating in endocannabinoid inactivation. Proc Natl Acad Sci U S A 99:10819-10824. CrossRef Medline

DiPatrizio NV, Astarita G, Schwartz G, Li X, Piomelli D (2011) Endocannabinoid signal in the gut controls dietary fat intake. Proc Natl Acad Sci U S A 108:12904-12908. CrossRef Medline

Ferreira SH (1972) Prostaglandins, aspirin-like drugs and analgesia. Nat New Biol 240:200-203. CrossRef Medline

Fu J, Gaetani S, Oveisi F, Lo Verme J, Serrano A, Rodríguez De Fonseca F, Rosengarth A, Luecke H, Di Giacomo B, Tarzia G, Piomelli D (2003) Oleylethanolamide regulates feeding and body weight through activation of the nuclear receptor PPAR-alpha. Nature 425:90-93. CrossRef Medline

Fu J, Bottegoni G, Sasso O, Bertorelli R, Rocchia W, Masetti M, Guijarro A,
Lodola A, Armirotti A, Garau G, Bandiera T, Reggiani A, Mor M, Cavalli A, Piomelli D (2012) A catalytically silent FAAH-1 variant drives anandamide transport in neurons. Nat Neurosci 15:64-69. CrossRef Medline Gatta L, Piscitelli F, Giordano C, Boccella S, Lichtman A, Maione S, Di Marzo V (2012) Discovery of prostamide F2alpha and its role in inflammatory pain and dorsal horn nociceptive neuron hyperexcitability. PLoS One 7:e31111. CrossRef Medline

Gervois P, Mansouri RM (2012) PPARalpha as a therapeutic target in inflammation-associated diseases. Expert Opin Ther Targets 16:11131125. CrossRef Medline

Gregg LC, Jung KM, Spradley JM, Nyilas R, Suplita RL 2nd, Zimmer A, Watanabe M, Mackie K, Katona I, Piomelli D, Hohmann AG (2012) Activation of type 5 metabotropic glutamate receptors and diacylglycerol lipase-alpha initiates 2-arachidonoylglycerol formation and endocannabinoid-mediated analgesia. J Neurosci 32:9457-9468. CrossRef Medline

Guedes AG, Morisseau C, Sole A, Soares JH, Ulu A, Dong H, Hammock BD (2013) Use of a soluble epoxide hydrolase inhibitor as an adjunctive analgesic in a horse with laminitis. Vet Anaesth Analg 40:440-448. CrossRef Medline

Guindon J, Hohmann AG (2008) A physiological role for endocannabinoidderived products of cyclooxygenase-2-mediated oxidative metabolism. Br J Pharmacol 153:1341-1343. CrossRef Medline

Guindon J, Hohmann AG (2009) The endocannabinoid system and pain. CNS Neurol Disord Drug Targets 8:403-421. CrossRef Medline

Guindon J, Hohmann AG (2011) The endocannabinoid system and cancer: therapeutic implication. Br J Pharmacol 163:1447-1463. CrossRef Medline

Guindon J, Lai Y, Takacs SM, Bradshaw HB, Hohmann AG (2013) Alterations in endocannabinoid tone following chemotherapy-induced peripheral neuropathy: effects of endocannabinoid deactivation inhibitors targeting fatty-acid amide hydrolase and monoacylglycerol lipase in comparison to reference analgesics following cisplatin treatment. Pharmacol Res 67:94-109. CrossRef Medline

Herkenham M (1991) Characterization and localization of cannabinoid receptors in brain: an in vitro technique using slide-mounted tissue sections. NIDA Res Monogr 112:129-145. Medline

Hermanson DJ, Hartley ND, Gamble-George J, Brown N, Shonesy BC, Kingsley PJ, Colbran RJ, Reese J, Marnett LJ, Patel S (2013) Substrateselective COX-2 inhibition decreases anxiety via endocannabinoid activation. Nat Neurosci 16:1291-1298. CrossRef Medline

Hiura A, Sakamoto Y (1987) Quantitative estimation of the effects of capsaicin on the mouse primary sensory neurons. Neurosci Lett 76:101-106. CrossRef Medline

Hohmann AG, Herkenham M (1999) Cannabinoid receptors undergo axonal flow in sensory nerves. Neuroscience 92:1171-1175. CrossRef Medline

Hohmann AG, Suplita RL, Bolton NM, Neely MH, Fegley D, Mangieri R, Krey JF, Walker JM, Holmes PV, Crystal JD, Duranti A, Tontini A, Mor M, Tarzia G, Piomelli D (2005) An endocannabinoid mechanism for stress-induced analgesia. Nature 435:1108-1112. CrossRef Medline

Inceoglu B, Wagner K, Schebb NH, Morisseau C, Jinks SL, Ulu A, Hegedus C, Rose T, Brosnan R, Hammock BD (2011) Analgesia mediated by soluble epoxide hydrolase inhibitors is dependent on cAMP. Proc Natl Acad Sci U S A 108:5093-5097. CrossRef Medline

Inceoglu B, Wagner KM, Yang J, Bettaieb A, Schebb NH, Hwang SH, Morisseau C, Haj FG, Hammock BD (2012) Acute augmentation of epoxygenated fatty acid levels rapidly reduces pain-related behavior in a rat model of type I diabetes. Proc Natl Acad Sci U S A 109:11390-11395. CrossRef Medline

Inceoglu B, Zolkowska D, Yoo HJ, Wagner KM, Yang J, Hackett E, Hwang SH, Lee KS, Rogawski MA, Morisseau C, Hammock BD (2013) Epoxy fatty acids and inhibition of the soluble epoxide hydrolase selectively modulate GABA mediated neurotransmission to delay onset of seizures. PLoS One 8:e80922. CrossRef Medline

Kathuria S, Gaetani S, Fegley D, Valiño F, Duranti A, Tontini A, Mor M, Tarzia G, La Rana G, Calignano A, Giustino A, Tattoli M, Palmery M, Cuomo V, Piomelli D (2003) Modulation of anxiety through blockade of anandamide hydrolysis. Nat Med 9:76-81. CrossRef Medline

Khasabova IA, Stucky CL, Harding-Rose C, Eikmeier L, Beitz AJ, Coicou LG, Hanson AE, Simone DA, Seybold VS (2007) Chemical interactions between fibrosarcoma cancer cells and sensory neurons contribute to cancer pain. J Neurosci 27:10289-10298. CrossRef Medline 
Khasabova IA, Khasabov SG, Harding-Rose C, Coicou LG, Seybold BA, Lindberg AE, Steevens CD, Simone DA, Seybold VS (2008) A decrease in anandamide signaling contributes to the maintenance of cutaneous mechanical hyperalgesia in a model of bone cancer pain. J Neurosci 28: 11141-11152. CrossRef Medline

Khasabova IA, Xiong Y, Coicou LG, Piomelli D, Seybold V (2012) Peroxisome proliferator-activated receptor alpha mediates acute effects of palmitoylethanolamide on sensory neurons. J Neurosci 32:12735-12743. CrossRef Medline

Khasabova IA, Holman M, Morse T, Burlakova N, Coicou L, Harding-Rose C, Simone DA, Seybold VS (2013) Increased anandamide uptake by sensory neurons contributes to hyperalgesia in a model of cancer pain. Neurobiol Dis 58:19-28. CrossRef Medline

Kostadinova R, Wahli W, Michalik L (2005) PPARs in diseases: control mechanisms of inflammation. Curr Med Chem 12:2995-3009. CrossRef Medline

Long JZ, Nomura DK, Cravatt BF (2009) Characterization of monoacylglycerol lipase inhibition reveals differences in central and peripheral endocannabinoid metabolism. Chem Biol 16:744-753. CrossRef Medline

LoVerme J, La Rana G, Russo R, Calignano A, Piomelli D (2005) The search for the palmitoylethanolamide receptor. Life Sci 77:1685-1698. CrossRef Medline

LoVerme J, Russo R, La Rana G, Fu J, Farthing J, Mattace-Raso G, Meli R, Hohmann A, Calignano A, Piomelli D (2006) Rapid broad-spectrum analgesia through activation of peroxisome proliferator-activated receptor-alpha. J Pharmacol Exp Ther 319:1051-1061. CrossRef Medline

Mantyh PW, Clohisy DR, Koltzenburg M, Hunt SP (2002) Molecular mechanisms of cancer pain. Nat Rev Cancer 2:201-209. CrossRef Medline

Marrs WR, Blankman JL, Horne EA, Thomazeau A, Lin YH, Coy J, Bodor AL, Muccioli GG, Hu SS, Woodruff G, Fung S, Lafourcade M, Alexander JP, Long JZ, Li W, Xu C, Möller T, Mackie K, Manzoni OJ, Cravatt BF, et al. (2010) The serine hydrolase ABHD6 controls the accumulation and efficacy of 2-AG at cannabinoid receptors. Nat Neurosci 13:951-957. CrossRef Medline

Mercadante S (1999) Pain treatment and outcomes for patients with advanced cancer who receive follow-up care at home. Cancer 85:1849-1858. CrossRef Medline

Mitrirattanakul S, Ramakul N, Guerrero AV, Matsuka Y, Ono T, Iwase H, Mackie K, Faull KF, Spigelman I (2006) Site-specific increases in peripheral cannabinoid receptors and their endogenous ligands in a model of neuropathic pain. Pain 126:102-114. CrossRef Medline

Moreno-Sanz G, Barrera B, Guijarro A, d'Elia I, Otero JA, Alvarez AI, Bandiera T, Merino G, Piomelli D (2011) The ABC membrane transporter ABCG2 prevents access of FAAH inhibitor URB937 to the central nervous system. Pharmacol Res 64:359-363. CrossRef Medline

Morisseau C, Hammock BD (2013) Impact of soluble epoxide hydrolase and epoxyeicosanoids on human health. Annu Rev Pharmacol Toxicol 53:37-58. CrossRef Medline

Morisseau C, Inceoglu B, Schmelzer K, Tsai HJ, Jinks SL, Hegedus CM, Hammock BD (2010) Naturally occurring monoepoxides of eicosapentaenoic acid and docosahexaenoic acid are bioactive antihyperalgesic lipids. J Lipid Res 51:3481-3490. CrossRef Medline

Nackley AG, Suplita RL 2nd, Hohmann AG (2003a) A peripheral cannabinoid mechanism suppresses spinal fos protein expression and pain behavior in a rat model of inflammation. Neuroscience 117:659-670. CrossRef Medline

Nackley AG, Makriyannis A, Hohmann AG (2003b) Selective activation of cannabinoid $\mathrm{CB}(2)$ receptors suppresses spinal fos protein expression and pain behavior in a rat model of inflammation. Neuroscience 119:747-757. CrossRef Medline

Nackley AG, Zvonok AM, Makriyannis A, Hohmann AG (2004) Activation of cannabinoid CB2 receptors suppresses C-fiber responses and windup in spinal wide dynamic range neurons in the absence and presence of inflammation. J Neurophysiol 92:3562-3574. CrossRef Medline

O'Sullivan SE, Kendall DA (2010) Cannabinoid activation of peroxisome proliferator-activated receptors: potential for modulation of inflammatory disease. Immunobiology 215:611-616. CrossRef Medline

Panigrahy D, Kalish BT, Huang S, Bielenberg DR, Le HD, Yang J, Edin ML, Lee CR, Benny O, Mudge DK, Butterfield CE, Mammoto A, Mammoto T, Inceoglu B, Jenkins RL, Simpson MA, Akino T, Lih FB, Tomer KB, Ingber DE, et al. (2013) Epoxyeicosanoids promote organ and tissue regeneration. Proc Natl Acad Sci U S A 110:13528-13533. CrossRef Medline

Pearce RJ, Duchen MR (1994) Differential expression of membrane cur- rents in dissociated mouse primary sensory neurons. Neuroscience 63: 1041-1056. CrossRef Medline

Piomelli D, Sasso O (2014) Peripheral gating of pain signals by endogenous lipid mediators. Nat Neurosci 17:164-174. CrossRef Medline

Pisanti S, Picardi P, D’Alessandro A, Laezza C, Bifulco M (2013) The endocannabinoid signaling system in cancer. Trends Pharmacol Sci 34:273282. CrossRef Medline

Price TJ, Patwardhan A, Akopian AN, Hargreaves KM, Flores CM (2004) Modulation of trigeminal sensory neuron activity by the dual cannabinoidvanilloid agonists anandamide, $\mathrm{N}$-arachidonoyl-dopamine and arachidonyl-2chloroethylamide. Br J Pharmacol 141:1118-1130. CrossRef Medline

Rahman IA, Tsuboi K, Uyama T, Ueda N (2014) New players in the fatty acyl ethanolamide metabolism. Pharmacol Res 86C:1-10. CrossRef Medline

Richardson D, Pearson RG, Kurian N, Latif ML, Garle MJ, Barrett DA, Kendall DA, Scammell BE, Reeve AJ, Chapman V (2008) Characterisation of the cannabinoid receptor system in synovial tissue and fluid in patients with osteoarthritis and rheumatoid arthritis. Arthritis Res Ther 10:R43. CrossRef Medline

Richardson JD, Kilo S, Hargreaves KM (1998) Cannabinoids reduce hyperalgesia and inflammation via interaction with peripheral CB1 receptors. Pain 75:111-119. CrossRef Medline

Ruiz-Medina J, Flores JA, Tasset I, Tunez I, Valverde O, Fernandez-Espejo E (2012) Alteration of neuropathic and visceral pain in female C57BL/6J mice lacking the PPAR-alpha gene. Psychopharmacology (Berl) 222:477488. CrossRef Medline

Sagar DR, Kelly S, Millns PJ, O'Shaughnessey CT, Kendall DA, Chapman V (2005) Inhibitory effects of $\mathrm{CB} 1$ and $\mathrm{CB} 2$ receptor agonists on responses of DRG neurons and dorsal horn neurons in neuropathic rats. Eur J Neurosci 22:371-379. CrossRef Medline

Sasso O, Bertorelli R, Bandiera T, Scarpelli R, Colombano G, Armirotti A, Moreno-Sanz G, Reggiani A, Piomelli D (2012) Peripheral FAAH inhibition causes profound antinociception and protects against indomethacininduced gastric lesions. Pharmacol Res 65:553-563. CrossRef Medline

Sasso O, Moreno-Sanz G, Martucci C, Realini N, Dionisi M, Mengatto L, Duranti A, Tarozzo G, Tarzia G, Mor M, Bertorelli R, Reggiani A, Piomelli D (2013) Antinociceptive effects of the $\mathrm{N}$-acylethanolamine acid amidase inhibitor ARN077 in rodent pain models. Pain 154:350-360. CrossRef Medline

Schmelzer KR, Kubala L, Newman JW, Kim IH, Eiserich JP, Hammock BD (2005) Soluble epoxide hydrolase is a therapeutic target for acute inflammation. Proc Natl Acad Sci U S A 102:9772-9777. CrossRef Medline

Schmelzer KR, Inceoglu B, Kubala L, Kim IH, Jinks SL, Eiserich JP, Hammock BD (2006) Enhancement of antinociception by coadministration of nonsteroidal anti-inflammatory drugs and soluble epoxide hydrolase inhibitors. Proc Natl Acad Sci U S A 103:13646-13651. CrossRef Medline

Schwei MJ, Honore P, Rogers SD, Salak-Johnson JL, Finke MP, Ramnaraine ML, Clohisy DR, Mantyh PW (1999) Neurochemical and cellular reorganization of the spinal cord in a murine model of bone cancer pain. J Neurosci 19:10886-10897. Medline

Serhan CN, Chiang N, Van Dyke TE (2008) Resolving inflammation: dual anti-inflammatory and pro-resolution lipid mediators. Nat Rev Immunol 8:349-361. CrossRef Medline

Shen HC, Hammock BD (2012) Discovery of inhibitors of soluble epoxide hydrolase: a target with multiple potential therapeutic indications. J Med Chem 55:1789-1808. CrossRef Medline

Solorzano C, Zhu C, Battista N, Astarita G, Lodola A, Rivara S, Mor M, Russo R, Maccarrone M, Antonietti F, Duranti A, Tontini A, Cuzzocrea S, Tarzia G, Piomelli D (2009) Selective N-acylethanolamine-hydrolyzing acid amidase inhibition reveals a key role for endogenous palmitoylethanolamide in inflammation. Proc Natl Acad Sci U S A 106:20966-20971. CrossRef Medline

Spradley JM, Guindon J, Hohmann AG (2010) Inhibitors of monoacylglycerol lipase, fatty-acid amide hydrolase and endocannabinoid transport differentially suppress capsaicin-induced behavioral sensitization through peripheral endocannabinoid mechanisms. Pharmacol Res 62:249-258. CrossRef Medline

Stella N, Schweitzer P, Piomelli D (1997) A second endogenous cannabinoid that modulates long-term potentiation. Nature 388:773-778. CrossRef Medline

Svízenská IH, Brázda V, Klusáková I, Dubový P (2013) Bilateral changes of cannabinoid receptor type 2 protein and mRNA in the dorsal root ganglia 
of a rat neuropathic pain model. J Histochem Cytochem 61:529-547. CrossRef Medline

Taylor BK, Dadia N, Yang CB, Krishnan S, Badr M (2002) Peroxisome proliferator-activated receptor agonists inhibit inflammatory edema and hyperalgesia. Inflammation 26:121-127. CrossRef Medline

Ueda N, Tsuboi K, Uyama T (2013) Metabolism of endocannabinoids and related $\mathrm{N}$-acylethanolamines: canonical and alternative pathways. FEBS J 280:1874-1894. CrossRef Medline

Ulu A, Stephen Lee KS, Miyabe C, Yang J, Hammock BG, Dong H, Hammock BD (2014) An omega-3 epoxide of docosahexaenoic acid lowers blood pressure in angiotensin-II-dependent hypertension. J Cardiovasc Pharmacol 64:87-99. CrossRef Medline

Wacnik PW, Eikmeier LJ, Ruggles TR, Ramnaraine ML, Walcheck BK, Beitz AJ, Wilcox GL (2001) Functional interactions between tumor and peripheral nerve: morphology, algogen identification, and behavioral characterization of a new murine model of cancer pain. J Neurosci 21:93559366. Medline

Wacnik PW, Baker CM, Herron MJ, Kren BT, Blazar BR, Wilcox GL, Hordinsky MK, Beitz AJ, Ericson ME (2005) Tumor-induced mechanical hyperalgesia involves CGRP receptors and altered innervation and vascularization of DsRed2 fluorescent hindpaw tumors. Pain 115:95-106. CrossRef Medline

Wagner K, Inceoglu B, Hammock BD (2011) Soluble epoxide hydrolase inhibition, epoxygenated fatty acids and nociception. Prostaglandins Other Lipid Mediat 96:76-83. CrossRef Medline

Wotherspoon G, Fox A, McIntyre P, Colley S, Bevan S, Winter J (2005) Peripheral nerve injury induces cannabinoid receptor 2 protein expression in rat sensory neurons. Neuroscience 135:235-245. CrossRef Medline

Xu D, Li N, He Y, Timofeyev V, Lu L, Tsai HJ, Kim IH, Tuteja D, Mateo RK, Singapuri A, Davis BB, Low R, Hammock BD, Chiamvimonvat N (2006) Prevention and reversal of cardiac hypertrophy by soluble epoxide hydrolase inhibitors. Proc Natl Acad Sci U S A 103:18733-18738. CrossRef Medline

Zhang G, Panigrahy D, Mahakian LM, Yang J, Liu JY, Stephen Lee KS, Wettersten HI, Ulu A, Hu X, Tam S, Hwang SH, Ingham ES, Kieran MW, Weiss RH, Ferrara KW, Hammock BD (2013) Epoxy metabolites of docosahexaenoic acid (DHA) inhibit angiogenesis, tumor growth, and metastasis. Proc Natl Acad Sci U S A 110:6530-6535. CrossRef Medline

Zhang G, Kodani S, Hammock BD (2014) Stabilized epoxygenated fatty acids regulate inflammation, pain, angiogenesis and cancer. Prog Lipid Res 53:108-123. CrossRef Medline

Zhu C, Solorzano C, Sahar S, Realini N, Fung E, Sassone-Corsi P, Piomelli D (2011) Proinflammatory stimuli control $\mathrm{N}$-acylphosphatidylethanolamine-specific phospholipase D expression in macrophages. Mol Pharmacol 79:786-792. CrossRef Medline 